\title{
EFEKTIVITAS PENGGUNAAN MEDIA FILM UNTUK MENINGKATKAN MINAT DAN HASIL BELAJAR EKONOMI SISWA KELAS X
}

\author{
Hayyun Lathifaty Yasri, Endang Mulyani \\ Program Pascasarjana Universitas Negeri Yogyakarta, Universitas Negeri Yogyakarta \\ hayyunlathifah@gmail.com, endangmulyani_uny@yahoo.com
}

\begin{abstract}
Abstrak
Penelitian ini dilakukan dengan tujuan untuk mengatahui: 1) efektivitas media film dalam meningkatkan minat dan hasil belajar Ekonomi siswa, 2) perbedaan peningkatan minat belajar siswa yang menggunakan media film dengan siswa yang tidak menggunakan media film, 3) perbedaan peningkatan hasil belajar siswa yang menggunakan media film dengan siswa yang tidak menggunakan media film. Penelitian ini merupakan penelitian kuantitatif dengan metode Quasi Experiment dengan Nonequivalent Control Group Design. Sampel diambil dengan teknik purposive sampling. Perlakuan dalam penelitian ini berupa penggunaan media film pada kelompok eksperimen dan tanpa media film pada kelompok kontrol. Data hasil belajar diperoleh dari tes tertulis dan data minat belajar diperoleh dari angket tertutup. Penelitian ini menghasilkan beberapa temuan, yaitu: 1) media film efektif untuk meningkatkan minat dan hasil belajar Ekonomi siswa, 2) terdapat perbedaan minat belajar siswa yang menggunakan media film dengan siswa yang tidak menggunakan media film, 3) terdapat perbedaan hasil belajar Ekonomi siswa yang menggunakan media film dengan siswa yang tidak menggunakan media film.
\end{abstract}

Kata kunci: film, minat belajar, hasil belajar

\section{THE EFFECTIVENESS OF FILM AS INSTRUCTIONAL MEDIA TO ENHANCE GRADE X STUDENT'S LEARNING INTEREST AND LEARNING OUTCOME}

\author{
Hayyun Lathifaty Yasri, Dr. Endang Mulyani, M. Si \\ Program Pascasarjana Universitas Negeri Yogyakarta, Universitas Negeri Yogyakarta \\ hayyunlathifah@gmail.com, endangmulyani_uny@yahoo.com
}

\begin{abstract}
This study aims to know: a) level of film effectiveness to enhance learning interest and learning outcome of student on economic lesson, b) the difference between student learning interest of experimental class and control class, and c) the difference between student learning outcome of experimental class and control class. This study employed quantitative approach that use Quasi Experiment method by Pretest Posttest Control Group Design. The subject of this study taken by purposive sampling technique from the population is all class of grade X. The data were collected by questionnaire and test of learning outcome. The findings of this study are: 1) the film was proven that effective to enhance learning interest and learning outcome of student on economic lesson, 2) there a difference between student learning interest of experimental class with a student learning interest of control class, and there a difference between student learning outcome of experimental class with a student learning outcome of control class.
\end{abstract}

Keywords: film, learning interest, learning outcome 


\section{Pendahuluan}

SMA N 1 Sampung merupakan SMA tunggal di kecamatan Sampung Ponorogo. SMA yang berada jauh dari perkotaan ini telah mampu mencapai penialain akreditasi B (gembung) dengan skor 83 . Kondisi ini ternyata tidak sesuai dengan kondisi pembelajaran yang dilaksanakan di dalam kelas. Hal ini ditunjukkan dengan masih ditemukannya permasalah-permasalahan dalam pembelajaran diantaranya ialah minat belajar yang masih rendah dan hasil belajar yang kurang. Pada permasalahan minat belajar yang masih rendah, hal ini sesuai dengan hasil wawancara dengan guru mata pelajaran Ekonomi tanggal 17 April 2015 yang menyatakan bahwa guru telah berupaya dalam membuat pembelajaran lebih menarik dengan melaksanakan pembelajaran menggunakan media lingkungan, seperti koperasi, UMKM, dll. Namun, cara ini mengalami kendala pada proses perizinan pihak lembaga setempat yang kadang terkesan sulit diperoleh, sehingga upaya ini belum dapat memberikan hasil yang maksimal. Hal ini ditunjukkan dengan masih rendahnya minat siswa yang tercermin dari rendahnya antusisme siswa dalam merespon pembelajaran yang berlangsung. Adapun pada permasalahan hasil belajar yang masih rendah, guru mata pelajaran Ekonomi di SMA N 1 Sampung, Ponorogo memberitahukan bahwa pada pelaksanaan ulangan harian, rata-rata kelas yang dicapai siswa belum memenuhi Kriteria Ketuntasan Minimal (KKM) yang berlaku.

Berdasarkan observasi awal sebelum penelitian, diketahui bahwa meskipun guru telah melaksanakan pembelajaran dengan memanfaatkan media lingkungan, namun minat dan hasil belajar siswa belum dapat ditingkatkan dengan maksimal. Daya kritis siswa belum terbentuk dengan baik, sehingga pembelajaran berbasis lingkungan cenderung lebih banyak memakan waktu dan tenaga dengan hasil yang kurang memuaskan. Salah satu penyebab munculnya permasalahan ini ialah kurangnya keberagaman media dan metode yang digunakan guru dalam pembelajaran di kelas.

Hamalik (2006, pp 30-32) menyebutkan bahwa minat untuk belajar dapat dipengaruhi oleh guru, metode pembelajaran, dan materi pembelajaran. Dengan demikian, guru memiliki andil penting dalam penentuan belajar siswa, sehingga guru dapat melaksanakan kewajibannya dan mencapai tujuan pembelajaran yang telah dirumuskannya.

Morris (2006, 5) menyebutkan bahwa kreativitas dalam pembelajaran menjadi hal utama yang harus diperhatikan guru. Hal ini karena kreativitas dalam pembelajaran mampu memunculkan motivasi yang tinggi, ekspektasi yang tinggi, serta kemampuan berkomunikasi dan mendengarkan yang baik. Selain itu, kreativitas dalam pembelajaran juga mampu menjadikan pembelajaran lebih menarik dan menginspirasi.

Otte $(1966,40)$ menyebutkan bahwa kreativitas dalam pembelajaran dapat diwujudkan dengan menghadirkan pengalaman-pengalam belajar bagi siswa. Dengan demikian, dapat dimengerti bahwa guru yang kreatif ialah guru yang mampu membimbing siswa untuk belajar melalui pengalaman yang diperolehnya. Edgar Dale (1946, pp 37-46) menyebutkan bahwa terdapat 11 macam pengalaman belajar siswa yaitu (1) pengalaman verbal, (2) pengalaman lambag visual, (3) pengalaman melalui radio, (4) pengalaman melalui film, (5) pengalaman melalui televisi, (6) pengalaman melalui pameran, (7) pengalaman karyawisata, (8) pengalaman demonstrasi, (9) pengalaman melalui drama, (10) pengalaman melalui benda tiruan, dan (11) pengalaman langsung.

Berdasarkan 11 macam pengalaman belajar yang disebutkan Dale di atas, dapat disimpulkan bahwa pengalaman belajar siswa salah satunya dapat diperoleh melalui film. Hal ini sesuai dengan yang tercantum dalam (Masterpiece) Film in the Classroom $(2011,6)$ menyebutkan bahwa siswa cenderung lebih banyak memahami halhal yang terinterpretasikan dalam film daripada dalam buku teks. Disebutkan pula bahwa film mampu memberikan pengalaman belajar yang tidak didapatkan siswa di dalam kelas karena keterbatasan ruang dan waktu yang mereka miliki. Hal ini juga dapat mengasah kemampuan analitis siswa terhadap Film yang ditampilkan berdasarkan teori dan konsep yang telah mereka pelajari sebelumnya. Selain itu, tingkat kehadiran siswa di dalam kelas dan perilakunyapun turut meningkat karenanya (Council Lottary Fundee, UK Film, 2010, 8). Dengan demikian dapat dinyatakan bahwa Film mampu mencapai ranah kognitif dan afektif siswa secara bersamaan (Champoux, 2007, p.12). 
Berdasarkan latar belakang tersebut, ditemukan beberapa permasalahan yang ada pada pembelajaran ekonomi di SMA N 1 Sampung Ponorogo, yaitu: Minat belajar ekonomi masih rendah, Lemahnya pemahaman siswa tentang konsep dasar Ekonomi, Hasil belajar Ekonomi siswa masih rendah, Kurangnya keberagaman metode pembelajaran yang digunakan guru pelajaran Ekonomi di dalam kelas, dan Kurangnya keberagaman media pembelajaran yang digunakan guru pelajaran Ekonomi di dalam kelas. Namun, pada penelitian ini permasalahan dibatasi pada masalah minat belajar ekonomi yang masih rendah dan hasil belajar ekonomi yang masih rendah saja.

Tujuan penelitian ini ialah untuk mengetahui: (1) efektivitas penggunaan media film terhadap peningkatan minat dan hasil belajar ekonomi siswa, (2) perbedaan peningkatan minat belajar ekonomi siswa yang menggunakan media film dengan siswa yang tidak menggunakan media dalam pembelajaran ekonomi, dan (3) perbedaan peningkatan hasil belajar ekonomi siswa yang menggunakan media film dengan siswa yang tidak menggunakan media dalam pembelajaran ekonomi.

Penelitian ini dilakukan dengan harapan dapat memberikan beberapa manfaat, baik manfaat secara teoritis maupun secara praktis. Manfaat teoritis yang diharapkan dapat diperoleh dari penelitian ini ialah: Memberikan kontribusi positif untuk menambah kekayaan keilmuan di bidang pemanfaatan media pembelajaran dan Menambah kekayaan keilmuan di bidang peningkatan minat dan hasil belajar siswa. Adapun manfaat praktis yang diharapkan dapat diperoleh dari penelitian ini ialah menjadi media penunjang belajar yang diharapkan dapat memberikan pemahaman yang mendalam terhadap materi yang disampaikan, baik konsep, materi, maupun penerapan dalam kehidupan nyata sehingga mampu meningkatkan hasil belajar siswa, menstimulus semangat, minat dan motivasi siswa dalam memahami segala hal yang terkandung dalam film dan mengaitkannya dengan materi yang dipelajari, menjadi media alternatif yang dapat digunakan guru untuk menunjang pembelajaran Ekonomi di SMA kelas X, menjadi salah satu sumber inspirasi bagi guru dalam mengkreasikan pembelajaran guna meningkatkan minat dan hasil belajar siswa, dan menjadi salah satu landasan bagi kepala sekolah untuk mengambil kebijakan berkenaan dengan upaya peningkatan minat dan hasil belajar siswa, salah satunya dengan menstimulus kreativitas guru dalam pembelajaran.

Definisi operasional dari kata film yang digunakan dalam penelitian ini ialah sebuah penyampaian cerita dalam bentuk audio-visual sebagai gambaran dari cerita kehidupan dan pengembangan emosi sebuah narasi yang disusun untuk menyampaikan sebuah konsep. Adapun minat belajar ialah segala sesuatu yang mampu mendorong seseorang untuk melakukan sesuatu karena ketertarikan yang spesifik terhadap suatu objek dengan perasaan gembira dan dengan tujuan tertentu. Ketertarikan ini dapat dilihat melalui partisipasi siswa selama pembelajaran berlangsung, kedisiplinannya dalam mengerjakan tugas, keterlibatannya dalam diskusi, kelengkapan catatan yang dimiliki, usaha yang dilakukan untuk memahami materi pelajaran ekonomi, tingkat kehadirannya di dalam kelas, perhatiannya terhadap penyampaian guru, dan perasaan yang dirasakannya selama pembelajaran berlangsung (senang, sedih, kecewa, atau dll.). Hasil belajar yang dimaksud dalam penelitian ini adalah sebuah kemampuan dan perubahan yang diperoleh karena dilaksanakannya pembelajaran. Adapun yang dimaksud hasil belajar pada penelitian ini ialah hasil belajar pada aspek kognitif siswa yang diukur dengan pemberian tes hasil belajar yang terdiri dari 4 soal. Keempat soal tersebut terdiri dari 1 soal yang mewakili pengetahuan siswa, 2 soal mewakili pemahaman siswa, dan 1 soal mewakili kemampuan siswa dalam mengevaluasi belajarnya. Penialaian yang digunakan berdasarkan skala 100 yang dikategorika menjadi 5 kelas, yaitu: skor $5-23$ untuk kategori Sangat Kurang (SK), 24 - 42 untuk kategori Kurang (K), 43 -61 untuk kategori cukup (C), 62 - 80 untuk kategori baik (B), dan 81 - 100 untuk kategori Sangat Baik (SB).

\section{Metode Penelitian}

Jenis Penelitian

Penelitian ini merupakan penelitian kuantitatif dengan metode quasi experiment. Adapun desain yang digunakan ialah nonequivalent control group design. Berikut adalah skema penggambaran desain Nonequivalent Control Group Design yang digunakan pada penelitian ini: 


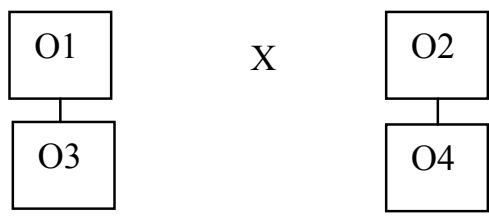

Gambar 1. Desain eksperimen dengan kelompok kontrol (nonequivalent control group design)

Keterangan:

O1 : Pretest kelompok ksperimen

O3 : Pretest kelompok control

$\mathrm{X}$ : Perlakuan

O2 : Posttest kelompok eksperimen

O4 : Posttest kelompok kontrol

Gambar tersebut dapat dijelaskan bahwa $\mathrm{O} 1$ merupakan nilai kemampuan awal kelompok eksperimen, dan $\mathrm{O} 3$ adalah nilai kemampuan awal kelompok kontrol. Setelah kemampuan kedua kelompok seimbang, kelompok eksperimen diberikan treatment/ perlakuan berupa penggunaan media film dan kelompok kontrol tidak menggunakan media film. Selanjutnya, kinerja kelompok eksperimen setelah diberi perlakuan ditunjukkan oleh $\mathrm{O} 2$ dan kinerja kelompok kontrol ditunjukkan oleh O4. Bila nilai kinerja pada $\mathrm{O} 2$ cenderung lebih tinggi, maka sistem kerja media film dapat dinyatakan lebih efektif dibandingkan dengan sistem kerja metode lama yang biasa digunakan sebagaimana digunakan pada kelompok kontrol (Sugiono, 2012). Adapun desain pembelajaran yang dilaksanakan pada kedua subjek penelitian yang terdiri dari satu kelompok eksperimen dan satu kelompok kontrol dapat dilihat pada tabel berikut ini:

Tabel 1. Desain Pembelajaran

\begin{tabular}{ccl}
\hline Kelompok & Kelas & \multicolumn{1}{c}{ Jenis Perlakuan } \\
\hline Eksperimen & X1 & $\begin{array}{l}\text { Pembelajaran } \\
\text { berbantuan media Film } \\
\text { dan Diskusi }\end{array}$ \\
Kontrol & X2 & $\begin{array}{l}\text { Pembelajaran berbasis } \\
\text { diskusi tanpa media } \\
\text { film pembelajaran }\end{array}$ \\
\hline
\end{tabular}

Adapun hipotesis yang diajukan dalam penelitian ini ialah: (1) film efektif meningkatkan minat dan hasil belajar Ekonomi siswa kelas X SMA N 1 Sampung Ponorogo, (2) terdapat perbedaan peningkatan minat belajar siswa yang menggunakan media film dengan siswa yang tidak menggunakan media film dalam pembelajaran Ekonomi, dan (3) terdapat perbedaan peningkatan hasil belajar siswa yang menggunakan media film dengan siswa yang tidak menggunakan media film dalam pembelajaran Ekonomi.

Waktu dan Tempat Penelitian

Penelitian ini dilakukan pada bulan AprilMei 2015, yaitu pada akhir semester genap (II) tahun ajaran 2014/2015. Adapun tempat dilakukannya penelitian ini ialah di SMA N 1 Sampung, Ponorogo.

\section{Target/Subjek Penelitian}

Subjek penelitian ini adalah siswa kelas $X$ SMA N 1 Sampung Ponorogo yang terdiri dari kelas X1, X2, X3 dan X4. Pengambilan sampel dilakukan dengan teknik purposive sampling yang menghasilkan kelas X1 sebagai kelompok eksperimen dan kelas X2 sebagai kelompok kontrol. Tenik ini merupakan teknik pengambilan sampel berdasarkan ketentuan tertentu. Pada penelitian ini, data ketentuan yang diambil ialah karakteristik siswa kedua kelompok yang mendekati sama. Karakteristik tersebut diantaranya ialah memiliki nilai ratarata UAS yang mendekati sama, guru pengampu mata pelajaran Ekonomi yang sama, latar belakang (sebagai kelas IPA percobaan K13) yang sama dan rata-rata umur siswa antara kedua kelas yang hampir sama. Berdasarkan beberapa pertimbangan di atas peneliti memilih kelas X1 dan X2 sebagai subjek penelitian.

Prosedur

Berdasarkan desain penelitian yang digunakan, penenlitian ini diawali dengan pemberian pretest $\left(\mathrm{O}_{1}\right)$ pada kedua kelompok (kelompok eksperimen dan kelompok kontrol). Pemberian pretest $\left(\mathrm{O}_{1}\right)$ dilakukan untuk mengetahui minat dan hasil belajar siswa sebelum adanya perlakuan pembelajaran. Selanjutnya diberikan perlakuan berupa penggunaan media film pada pembelajaran Ekonomi di kelompok eksperimen (X1) dan pelakasanaan pembelajaran tanpa media film pada kelompok kontrol (X2). Adanya perlakuan dalam pembelajaran ditindaklanjuti dengan pemberian posttest $\left(\mathrm{O}_{2}\right)$ pada siswa kedua kelompok. Pemberian posttest $\left(\mathrm{O}_{2}\right)$ dilakukan untuk mengetahui peningkatan 
minat dan hasil belajar siswa pada masingmasing kelompok.

\section{Data, Instrumen dan Teknik Pengumpulan Data}

Data penelitian diperoleh dengan angket tertutup untuk minat belajar siswa dan tes tertulis untuk hasil belajar siswa. Instrumen angket minat belajar terdiri dari 8 indikator dengan 17 butir pernyataan dengan alternative jawaban berskala 5. Adapun instrument tes hasil belajar terdiri dari 4 soal uraian yang dinilai dengan point method, yaitu teknik penilaian dengan dasar poin-poin jawaban yang mampu disebutkan siswa.

Adapun pedoman penskoran data minat dan hasil belajar digunakan rumus yang diadaptasi dari Widoyoko $(2009,238)$ sebagai berikut:

Tabel 2. Rumus Kategori Minat dan Hasil Belajar Siswa

\begin{tabular}{lc}
\hline \multicolumn{1}{c}{ Kategori } & Rumus Logis \\
\hline Sangat Baik & $\mathrm{X}>\overline{\mathrm{X} i}+1,8$ Sbi \\
Baik & $\overline{\mathrm{X}} \mathrm{i}+0,6 \mathrm{Sbi}<\mathrm{X}<\overline{\mathrm{X}} \mathrm{i}+1,8$ Sbi \\
Cukup & $\overline{\mathrm{X}} \mathrm{i}-0,6 \mathrm{Sbi}<\mathrm{X}<\overline{\mathrm{X}} \mathrm{i}+0,6 \mathrm{Sbi}$ \\
Kurang & $\overline{\mathrm{X}} \mathrm{i}-1,8 \mathrm{Sbi}<\mathrm{X}<\overline{\mathrm{X}} \mathrm{i}-0,6 \mathrm{Sbi}$ \\
Sangat Kurang & $\mathrm{X}<\overline{\mathrm{X}} \mathrm{i}-1,8 \mathrm{Sbi}$ \\
\hline
\end{tabular}

Keterangan:

Xmax i = Skor Maksimal

Xmin i = Skor Minimal

$\mathrm{Xi} \quad=$ Rerata Ideal $=1 / 2(\mathrm{Xmax} \mathrm{i}+\mathrm{Xmin} \mathrm{i})$

Sbi $=$ Simp Baku Ideal $=1 / 6($ Xmax $\mathrm{i}-\mathrm{X}$ $\min$ i)

Kriteria pengkategorian tersebut merupakan acuan untuk mengidentifikasikan kondisi minat dan hasil belajar ekonomi siswa terhadap pembelajaran Ekonomi yang dilaksanakan di dalam kelas.

Adapun validitas instrument yang digunakan dalam penelitian ini ialahvaliditas internal yang terdiri dari validitas isi dan validitas konstruk. Validitas isi diperoleh dari pendapat ahli dan validitas konstruk diperoleh dari uji coba lapangan. Data hasil uji coba selanjutnya dianalisis dengan spearman rho untuk data minat belajar, dan uji tingkat kesukaran serta uji daya beda masing-masing soal untuk tes hasil belajar.

Reliabilitas instrument pada penelitian ini diperoleh dari pengujian Cronbach's alpha pada data minat dan hasil belajar.

\section{Teknik Analisis Data}

Data minat dan hasil belajar siswa yang telah diperoleh selanjutnya dianalisis dengan analisis deskriptif dan uji hipotesis yang terdiri dari uji manova dan uji t.

Analisis deskriptif dilakukan untuk mengatahui deskrispsi umum data seperti rerata pencapaian minat dan hasil belajar siswa, sedangkan uji hipotesis dilakukan untuk mengetahui apakan hipotesis yang diajukan dapat diterima atau ditolak.

Adapun hipotesis yang diajukan dalam penelitian ini ialah: (1) media film efektif meningkatkan minat dan hasil belajar Ekonomi siswa kelas X SMA N 1 Sampung, Ponorogo, (2) terdapat perbedaan peningkatan minat belajar Ekonomi siswa yang menggunakan media film dengan siswa yang tidak menggunakan media film, (3) terdapat perbedaan peningkatan hasil belajar Ekonomi siswa yang menggunakan media film dengan siswa yang tidak menggunakan media film.

Sebelum pengujian hipotesis, dilakukan pengujian prasyarat yang terdiri dari uji normalitas dan homogenitas data. Uji normalitas pada penelitian ini dilakukan dengan uji Kolomogrof Smirnov dan uji homogenitas dilakukan dengan uji Box's M pada manova.

\section{Hasil Penelitian dan Pembahasan}

Pelaksanaan penelitian ini dilakukan dengan beberapa tahap, yaitu: (1) mengajukan perizinan penelitian, (2) melakukan pra-survey, (3) berdiskusi dengan guru mata pelajaran ekonomi tentang media pembelajaran yang biasa digunakan dan yang belum pernah digunakan, (4) berdiskusi dengan guru mata pelajaran ekonomi berkenaan dengan karakteristik siswa, (5) menyusun RPP untuk masing-masing kelas eksperimen dan kelas kontrol, (6) melaksanakan pretest yang kemudian dilanjutkan dengan pemberian perlakuan, (7) melaksanakan posttest setelah pemberian perlakuan, terakhir (8) melakukan olah data penelitian.

Pada pertemuan pertama, kelas eksperimen mendapatkan perlakuan berupa pemberian pretest yang dilanjutkan dengan pembelajaran awal. Pembelajaran awal dilakukan dengan pemberian pengantar konsep dasar materi Permintaan dan Penawaran Uang yang dilanjutkan dengan 
penayangan film dengan frekuensi 2 kali putar. Pemutaran film diawali dengan pemberian petunjuk penugasan siswa selama proses pembelajaran berlangsung. Tugas pertama yang harus dilakukan siswa ialah mengamati film yang diputarkan dan menyusun sebuah outline materi yang mereka peroleh dari film tersebut. Tugas ini diberikan untuk dijadikan bahan acuan belajar siswa mengenai materi Permintaan dan Penawaran Uang yang disampaikan dengan media film.

Tugas pada pertemuan pertama ditindak lanjuti dengan kegiatan pada pertemuan kedua yaitu diskusi kelompok. Siswa dibagi menjadi 5 kelompok yang masing-masing kelompok beranggotakan 4-5 orang siswa. Pada kegiatan ini masing-masing kelompok diberikan satu materi khusus yang harus didiskusikan dan digali informasinya dari berbagai sumber. Siswa diberikan keleluasaan dalam memanfaatkan sumber-sumber belajar yang ada di sekitarnya termasuk internet. Selanjutnya siswa menuliskan hasil temuan dan diskusi mereka dalam sebuah lembaran untuk kemudian dipresentasikan di depan kelas.

Pada pertemuan ketiga, masing-masing kelompok diberikan waktu untuk mempresentasikan hasil diskusi yang telah dilakukannya dan menjelaskan kepada teman-temannya yang lain. Penjelasan yang disampaikan siswa kemudian dikonfirmasi dan direvisi kembali oleh guru jika ada yang kurang tepat atau perlu ditambahkan penjelasannya.

Perbedaan perlakuan antara kelompok ekseperimen dan kelompok kontrol terdapat pada kegiatan pada pertemuan pertama, yaitu pada kelompok kontrol tidak diberikan perlakuan berupa penggunaan media film dalam pembelajaran, namun pembelajaran dilaksanakan sebagaimana biasanya menggunakan metode ceramah tanpa media film. Pada proses penyampaian materi dengan ceramah ini, sesekali guru menuliskan poin-poin penting yang harus diingat siswa di papan tulis. Penyampaian materi dilakukan dengan singkat padat dan jelas, hal ini untuk memastikan bahwa pemahaman awal siswa pada kelompok eksperimen dan kelompok kontrol tidak terpaut jauh.

Penelitian diawali dengan pemberian pretest sebelum pembelajaran, hal ini untuk mengetahui kondisi minat dan hasil belajar ekonomi siswa sebelum pembelajaran. Hasil ini menentukan pengambilan keputusan tentang apakah kedua kelompok yang terpilih sebagai sampel setara, sehingga memenuhi kriteria penelitian ataukah harus ada pemilihan sampel lain yang setara. Setelah pemberian pretest, penelitian dilanjutkan dengan pemberian perlakuan pada kedua kelompok (kelompok eksperimen dan kelompok kotrol). Perlakuan pada kelompok eksperimen berupa penggunaan media film dalam pembelajaran dan pada kelompok kontrol adalah pelaksanaan pembelajaran tanpa media film dalam pembelajaran. Setelah dilakukan perlakuan, penelitian ditutup dengan pemberian posttest pada masing-masing siswa pada masingmasing kelompok. Pemberian posttest dilakukan untuk mengetahui peningkatan minat dan hasil belajar masing-masing siswa pada masingmasing kelompok sesudah adanya perlakuan.

Data hasil penelitian dianalisis dengan dua tahap, yaitu analisis deskriptif yang kemudian dilanjutkan analisis inferensial. Analisis deskriptif bertujuan untuk menampilkan gambaran data, seperti rerata dan distribusi kategorik. Sedangkan analisis inferensial yang digunakan dalam penelitian ini adalah MANOVA dan uji $t$ yang diawali uji asumsi atau prasyarat analisis. Analisis deskriptif dilakukan untuk mengetahui deskripsi dan kategori minat dan hasil belajar Ekonomi siswa, sedangkan analisis inferensial melalaui analisis Manova dan uji $t$ dilakukan untuk mengetahui efektivitas media film dalam meningkatkan minat dan hasil belajar Ekkonomi siswa.

Hasil yang diperoleh dalam penelitian ini menunjukkan bahwa kondisi minat belajar siswa sebelum pembelajaran dilaksanakan bersifat homogen. Hal ini terbukti dengan rerata skor minat belajar kedua kelompok yang mendekati sama, yaitu skor pada kelompok eksperimen sebesar 56,81 dan skor pada kelompok kontrol ialah 56,70. Dengan demikian, minat belajar Ekonomi siswa pada kedua kelompok sebelum pembelajaran hanya terpaut skor 0,11 dengan skor kelompok kontrol yang lebih tinggi.

Selanjutnya peneliti memberikan perlakuan yang berbeda pada kedua kelompok, yaitu pada kelompok eksperimen diberikan perlakuan berupa pembelajaran dengan media film yang dilanjutkan dengan diskusi kelompok, sedangkan pada kelompok kontrol pembelajaran 
dilaksanakan tanpa menggunakan media film yang dilanjutkan dengan metode diskusi sebagaimana yang biasa dilaksanakan pada proses pembelajaran sehari-hari.

Berdasarkan data yang didapatkan, diperoleh hasil yang menunjukkan adanya perbedaan minat belajar Ekonomi siswa sebelum dan sesudah pembelajaran. Perbedaan ini ditunjukkan dengan rerata skor minat belajar Ekonomi yang dicapai kelompok eksperimen sebelum pembelajaran 56,81 meningkat menjadi 70,43 dan kelompok kontrol 56,70 meningkat menjadi 64,90. Efektivitas media film dalam meningkatkan minat belajar Ekonomi siswa dapat dilihat dari peningkatan skor yang dicapai siswa kelompok eksperimen dibandingkan dengan peningkatan skor yang dicapai siswa kelompok kontrol. Adapun skor peningkatan minat belajar Ekonomi yang dicapai siswa kelompok eksperimen ialah 13,62, sedangkan skor peningkatan minat belajar Ekonomi siswa kelompok kontrol ialah 8,20. Berikut adalah tabel perbandingan pencapaian skor rerata minat belajar siswa kelompok eksperimen dan kelompok kontrol sebelum dan sesudah pembelajaran:

Tabel 3. Rerata Skor Peningkatan Minat Belajar Ekonomi Siswa Kelas X

\begin{tabular}{cccc}
\hline Keterangan & Sebelum & Sesudah & Peningkatan \\
\hline Eksperimen & 56,81 & 70,43 & $\mathbf{1 3 , 6 2}$ \\
Kontrol & 56,70 & 64,90 & $\mathbf{8 , 2}$ \\
\hline
\end{tabular}

Kondisi minat belajar ekonomi siswa tersebut dapat diklasifikasikan menjadi 5 kategori, yang terdiri dari Sangat Baik, Baik, Cukup, Kurang, dan Sangan Kurang. Berdasarkan kriteria pengaktegorian yang diadaptasi dari Widoyoko (2009, 238), diperoleh hasil klasifikasi minat belajar ekonomi siswa kelompok eksperimen dan kelompok kontrol sebelum pembelajaran sebagai berikut:

Tabel 4. Minat Belajar Ekonomi Siswa Sebelum Pembelajaran

\begin{tabular}{|cccccc}
\hline Kategori & Rentang & \multicolumn{5}{c}{ Kelompok } \\
\cline { 3 - 6 } & Skor & \multicolumn{2}{c}{ Eksperimen } & \multicolumn{2}{c}{ Kontrol } \\
& & F & $\%$ & F & $\%$ \\
Sangat & $17-30,5$ & 0 & 0,0 & 1 & 5,0 \\
Kurang & & & & & \\
Kurang & $30,6-44,1$ & 3 & 15,0 & 4 & 20,0 \\
Cukup & $44,2-57,7$ & 14 & 66,0 & 12 & 60,0
\end{tabular}

Tabel 4. Lanjutam

\begin{tabular}{lccccc}
\hline Kategori & Rentang & \multicolumn{4}{c}{ Kelompok } \\
\cline { 3 - 6 } & Skor & Eksperimen & \multicolumn{2}{c}{ Kontrol } \\
& & $\mathrm{F}$ & $\%$ & $\mathrm{~F}$ & $\%$ \\
Baik & $57,8-71,3$ & 4 & 19,0 & 3 & 15,0 \\
Sangat & $71,4-85$ & 0 & 0,0 & 0 & 0,0 \\
Baik & & & & & \\
\multicolumn{2}{c}{ Total } & 21 & 100 & 20 & 100 \\
\hline
\end{tabular}

Jika digambarkan dalam sebuah grafik, perbandingan minat belajar ekonomi kelompok eksperimen dan kelompok kontrol sebelum pembelajaran ialah sebagai berikut:

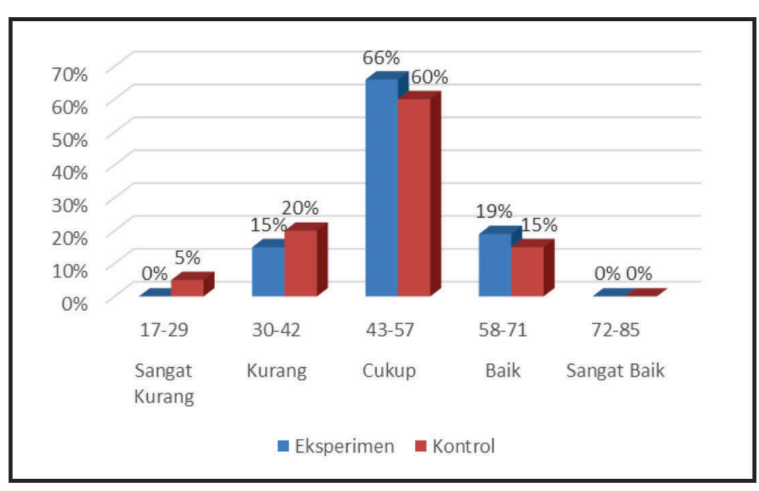

Gambar 2. Grafik minat belajar siswa sebelum pembelajaran

Adapun hasil klasifikasi minat belajar ekonomi siswa kelompok eksperimen dan kelompok kontrol sesudah pembelajaran sebagai berikut:

Tabel 5. Minat Belajar Ekonomi Siswa Sesudah Pembelajaran

\begin{tabular}{lccccc}
\hline Kategori & Rentang & \multicolumn{4}{c}{ Kelompok } \\
\cline { 3 - 6 } & Skor & \multicolumn{2}{c}{ Eksperimen } & \multicolumn{2}{c}{ Kontrol } \\
& & F & $\%$ & F & $\%$ \\
Sangat & $17-30,5$ & 0 & 0,0 & 0 & 0,0 \\
Kurang & & & & & \\
Kurang & $30,6-44,1$ & 0 & 0,0 & 0 & 0,0 \\
Cukup & $44,2-57,7$ & 0 & 0,0 & 1 & 5,0 \\
Baik & $57,8-71,3$ & 13 & 62,0 & 17 & 85,0 \\
Sangat & $71,4-85$ & 8 & 38,0 & 2 & 10,0 \\
Baik & & & & & \\
\multicolumn{1}{c}{ Total } & 21 & 100 & 20 & 100 \\
\hline
\end{tabular}

Jika digambarkan dalam sebuah grafik minat belajar ekonomi siswa kelompok eksperimen dan kelompok kontrol sesudah pembelajaran ialah sebagai berikut: 


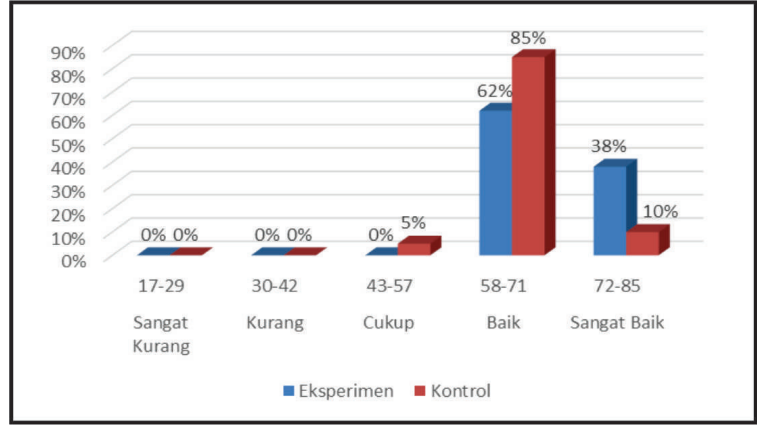

Gambar 3. Grafik minat belajar siswa sesudah pembelajaran

Berdasarkan rangkuman hasil analisis data yang telah dilakukan di atas, tampak jelas bahwa peningkatan skor minat belajar Ekonomi siswa kelompok eksperimen lebih tinggi dari peningkatan minat belajar Ekonomi siswa kelompok kontrol dengan selisih skor 5,42. Selain itu, berdasarkan kriteria efektivitas yang digunakan dalam penelitian ini, bahwasannya media dikatakan efektif jika skor minat belajar ekonomi yang dicapai siswa minimal berada pada kategori baik yaitu pada skor $\geq 57,8$, sehingga pada kedua kelompok terlihat bahwa pembelajaran menggunakan film memiliki efektivitas yang lebih tinggi daripada pembelajaran tanpa media film. Hasil ini sejalan dengan teori yang disampaikan oleh Munadi (2013, pp. 116-117) dan Champoux (2007, 11-12) bahwa salah satu manfaat film dalam pembelajaran ialah menumbuhkan atau meningkatkan minat belajar siswa.

Adapun pada variabel hasil belajar Ekonomi, diperoleh rerata skor siswa sebelum pembelajaran ialah 35,95 untuk kelompok eksperimen dan 36,0 untuk kelompok kontrol. Hasil belajar Ekonomi sebelum pembelajaran pada kedua kelompok tampak tidak berbeda jauh. Selisih rerata skor hasil belajar Ekonomi keduanya ialah 0,5 dengan kelompok kontrol yang lebih unggul, sehingga kedua kelompok dapat dinyatakan memiliki minat belajar Ekonomi sebelum pembelajaran yang setara.

Selanjutnya, setelah dilaksanakan pembelajaran Ekonomi pada kedua kelompok, peneliti melakukan pengukuran ulang pada hasil belajar Ekonomi siswa kedua kelompok. Berdasarkan hasil yang diperoleh, ditemukan hasil yang menunjukkan adanya perbedaan hasil belajar Ekonomi siswa sebelum dan sesudah pembelajaran. Perbedaan ini ditunjukkan dengan rerata skor hasil belajar Ekonomi yang dicapai kelompok eksperimen sebelum pembelajaran 35,95 meningkat menjadi 79,05 dan kelompok kontrol 36,0 meningkat menjadi 69,25. Efektivitas media film dalam meningkatkan hasil belajar Ekonomi siswa dapat dilihat dari peningkatan skor yang dicapai siswa kelompok eksperimen dibandingkan dengan peningkatan skor yang dicapai siswa kelompok kontrol. Adapun skor peningkatan hasil belajar Ekonomi yang dicapai siswa kelompok eksperimen ialah 43,10 , sedangkan skor peningkatan minat belajar Ekonomi siswa kelompok kontrol ialah 33,75.

Pada keadaan ini, diperoleh rerata peningkatan skor hasil belajar Ekonomi siswa lebih tinggi dari rerata peningkatan pada minat belajarnya. Hal ini ditunjukkan oleh rerata skor peningkatan yang dicapai oleh kelompok eksperimen pada kedua variabel tersebut. Pada variabel minat belajar, rerata skor peningkatan yang dicapai kelompok eksperimen ialah 13,38, sedangkan pada variabel hasil belajar, rerata skor peningkatan yang dicapai ialah 43,10. Dengan demikian peningkatan pada hasil belajar lebih unggul 29,72 dari pada peningkatan pada minat belajar. Selanjutnya, berdasarkan kriteria efektivitas yang digunakan dalam penelitian ini, bahwasannya media dikatakan efektif jika skor hasil belajar ekonomi yang dicapai siswa minimal berada pada batas KKM yang ditentukan, yaitu pada skor $\geq 75$, sehingga pada capaian skor kelompok eksperimen sebesar 79,0 dan kelompok kontrol sebesar 69,25 menunjukkan bahwa pembelajaran menggunakan film pada kelompok eksperimen memiliki efektivitas yang lebih tinggi daripada pembelajaran tanpa media film pada kelompok kontrol. Berikut adalah tabel perbandingan pencapaian skor rerata hasil belajar siswa kelompok eksperimen dan kelompok kontrol sebelum dan sesudah pembelajaran:

Tabel 6. Rerata Skor Peningkatan Hasil Belajar Ekonomi Siswa Kelas X

\begin{tabular}{lccc}
\hline Keterangan & Pretest & Posttest & Peningkatan \\
\hline Eksperimen & 35,95 & 79,05 & $\mathbf{4 3 , 0 5}$ \\
Kontrol & 36,00 & 69,25 & $\mathbf{3 3 , 2 5}$ \\
\hline
\end{tabular}

Kondisi hasil belajar ekonomi siswa tersebut dapat diklasifikasikan menjadi 5 kategori, yang terdiri dari Sangat Baik, Baik, Cukup, Kurang, dan Sangan Kurang. Berdasarkan kriteria pengaktegorian yang diadaptasi dari Widoyoko 
(2009, 238), diperoleh hasil klasifikasi hasil belajar ekonomi siswa kelompok eksperimen dan kelompok kontrol sebelum pembelajaran sebagai berikut:

Tabel 7. Hasil Belajar Ekonomi Siswa Sebelum Pembelajaran

\begin{tabular}{lccccc}
\hline Kategori & Rentang & \multicolumn{5}{c}{ Kelompok } \\
\cline { 3 - 6 } & skor & Eksperimen & \multicolumn{3}{c}{ Kontrol } \\
& & $\mathrm{F}$ & $\%$ & $\mathrm{~F}$ & $\%$ \\
Sangat & $81-100$ & 0 & 0,0 & 0 & 0,0 \\
Baik & & & & & \\
Baik & $62-80$ & 0 & 0,0 & 0 & 0,0 \\
Cukup & $43-61$ & 7 & 34,0 & 6 & 30,0 \\
Kurang & $24-42$ & 8 & 38,0 & 10 & 50,0 \\
Sangat & $5-23$ & 6 & 28,0 & 4 & 20,0 \\
Kurang & & & & & \\
\multicolumn{1}{c}{ Jumlah } & 21 & 100 & 20 & 100 \\
\hline
\end{tabular}

Jika digambarkan dalam sebuah grafik, perbandingan hasil belajar ekonomi kelompok eksperimen dan kelompok kontrol sebelum pembelajaran ialah sebagai berikut:

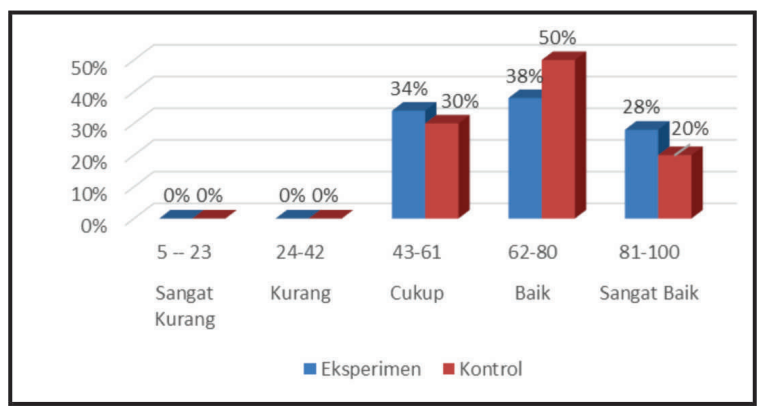

Gambar 4. Grafik hasil belajar siswa sebelum pembelajaran

Adapun klasifikasi hasil belajar ekonomi siswa kelompok eksperimen dan kelompok kontrol sesudah pembelajaran sebagai berikut:

Tabel 8. Hasil Belajar Ekonomi Siswa Sesudah Pembelajaran

\begin{tabular}{lccccc}
\hline Kategori & Rentang & \multicolumn{4}{c}{ Kelompok } \\
\cline { 3 - 6 } & skor & Eksperimen & \multicolumn{2}{c}{ Kontrol } \\
& & $\mathrm{F}$ & $\%$ & $\mathrm{~F}$ & $\%$ \\
Sangat & $81-100$ & 9 & 43,0 & 2 & 10,0 \\
Baik & & & & & \\
Baik & $62-80$ & 11 & 52,0 & 13 & 65,0 \\
Cukup & $43-61$ & 1 & 5,0 & 5 & 25,0 \\
Kurang & $24-42$ & 0 & 0,0 & 0 & 0,0
\end{tabular}

Gambar 4. Lanjutan

\begin{tabular}{lccccc}
\hline Kategori & Rentang & \multicolumn{4}{c}{ Kelompok } \\
\cline { 3 - 6 } & skor & \multicolumn{2}{c}{ Eksperimen } & \multicolumn{2}{c}{ Kontrol } \\
& & $\mathrm{F}$ & $\%$ & $\mathrm{~F}$ & $\%$ \\
Sangat & $5-23$ & 0 & 0,0 & 0 & 0,0 \\
Kurang & & & & & \\
\multicolumn{2}{c}{ Jumlah } & $\mathbf{2 1}$ & $\mathbf{1 0 0}$ & $\mathbf{2 0}$ & $\mathbf{1 0 0}$ \\
\hline
\end{tabular}

Adapun grafik hasil belajar ekonomi siswa kelompok eksperimen dan kelompok kontrol sesudah pembelajaran ialah sebagai berikut:

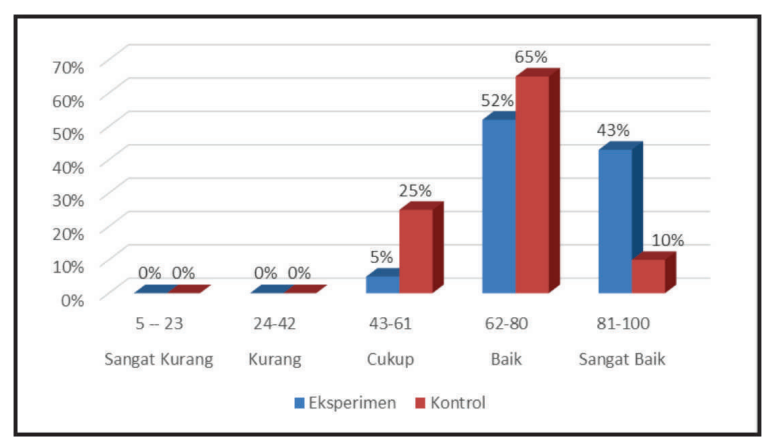

Gambar 5. Grafik hasil belajar siswa sesudah pembelajaran

Berdasarkan hasil penelitian ini, ditemukan capaian skor minat belajar dan hasil belajar kelompok eksperimen lebih tinggi dari pada kelompok kontrol. Hal ini karena pada proses pembelajaran berlangsung, siswa mendapatkan kesempatan untuk mengamati film secara visual, menganalisis dan menyampaikan kembali halhal terkait materi yang diperoleh dari media film. Penggunaan media film sebagai media audiovisual dalam pembelajaran memiliki daya tarik tersendiri dibandingkan penyampaian guru secara verbal atau tulisan (ceramah), sebagaimana yang diterapkan pada kelompok kontrol sebelum adanya diskusi kelompok. Hal ini berkenaan dengan upaya guru dalam membawa konsentrasi siswa pada pembelajaran melalui stimulasi minat belajar siswa dengan media film.

Penggunaan media film dalam pembelajaran merupakan salah satu hal yang melatarbelakangi peningkatan yang siginifikan pada hasil belajar siswa kelompok eksperimen. Hal ini karena pada masa perlakuan, siswa dituntut untuk lebih aktif mengamati, memahami dan menganalisis berbagai hal yang dilihat dan didengarnya dalam film tersebut. Hasil pengamatan ini diwujudkan dengan catatan pada poin-poin penting yang dibuat siswa selama 
film diputarkan. Bahkan, pada pelaksanaannya, film diputarkan sebanyak dua kali sebagaimana permintaan siswa. Dengan demikian siswa mampu membangun sendiri pengatahuannya melalui apa yang dilihat dan didengar. Pengalaman belajar inilah yang kemudian memberikan pengaruh pada peningkatan hasil belajar siswa. Hal ini sesuai dengan hasil penelitian yang dilakukan oleh Council Lottary Fundee, UK Film $(2010,8)$ bahwa menonton film memberikan dampak positif pada prestasi siswa, termasuk mengaktifkan siswa sehingga turut berperan dalam proses pembelajaran.

Selanjutnya, berdasarkan perhitungan yang dilakukan dengan Manova, diperoleh nilai Sig. (p) $0,000<0,05$ yang berarti bahwa bahwa film terbukti efektif dalam meningkatkan minat dan hasil belajar ekonomi siswa kelas X SMA N 1 Sampung Ponorogo. Pengujian secara terpisah dilakukan dengan uji t yang mengahasilkan nilai Sig. (p) pada uji perbedaan peningkatan skor minat belajar siswa kelompok eksperimen dan kelompok kontrol sebesar 0,001 $<0,05$ yang berarti bahwa terdapat perbedaan peningkatan minat belajar ekonomi kelompok eksperimen dan kelompok kontrol. Hasil ini sesuai dengan teori yang dinyatakan oleh Munadi (2013, pp. 116-117) dan Champoux (2007, pp. 11-12) yang menyatakan bahwa salah satu manfaat film dalam pembelajaran ialah menumbuhkan atau meningkatkan minat belajar siswa.

Selanjutnya, pada uji perbedaan peningkatan skor hasil belajar siswa kelompok eksperimen dan kelompok kontrol sebesar $0,014<0,05$ yang berarti bahwa terdapat perbedaan peningkatan hasil belajar ekonomi kelompok eksperimen dan kelompok kontrol. Dengan demikian, film terbukti efektif dalam meningkatkan minat dan hasil belajar ekonomi siswa kelas X SMA N 1 Sampung, Ponorogo. Hasil ini sesuai dengan temuan penelitian Council Lottary Fundee, UK Film (2010, 8) yang menyatakan bahwa menonton film dapat memberikan dampak positif terhadap prestasi belajar atau hasil belajar siswa.

Namun demikian, pelaksanaan proses pembelajaran pada kedua kelompok tidak dapat berjalan dengan optimal. Hal ini karena pada pelaksanaan pembelajaran materi Permintaan dan Penawaran Uang yang merupakan Kompetensi Dasar pertama dari Standar Kompetensi terakhir mengalami banyak benturan dengan berbagai kegiatan akhir tahun sekolah. Selain itu, jam pelajaran Ekonomi yang berada di jam terakhir turut menjadi hambatan, hal ini karena pada jamjam terakhir Kegiatan Belajar Mengajar (KBM) banyak digunakan untuk persiapan pelaksanaan perpisahan sekolah dengan siswa-siswa kelas XII. Keadaan yang kurang kondusif ini kemudian dikurangi dengan pengkondisian siswa yang dilakukan dengan bantuan guru pengampu mata pelajaran. Secara umum, hasil penelitian ini sejalan dengan hasil penelitian Wibowo (2015, 1) yang menemukan bahwa penerapan model pembelajaran Make a Match berbantuan media video berhasil meningkatkan motivasi dan hasil belajar siswa kelas VIII pada mata pelajaran IPS. Selain itu, disebutkan pula bahwa media video, yang pada konteks ini merupakan bagian media pembelajaran yang berbentuk audio visual sebagaiamana film, dinyatakan mampu mempermudah siswa untuk memahami materi pelajaran yang disampaikan di dalam kelas.

Seluruh uraian di atas merupakan pembahasan hasil penelitian eksperimen yang menggali informasi tentang efektivitas media film dalam meningkatkan minat dan hasil belajar Ekonomi siswa kelas X di SMA N 1 Sampung, Ponorogo. Berdasarkan hasil pembahasan tersebut dapat disimpulkan bahwa media film efektif dalam meningkatkan minat dan hasil belajar Ekonomi siswa kelas X SMA N 1 Sampung, Ponorogo, baik secara bersamaan maupun secara terpisah. Hal ini sesuai dengan teori yang disampaikan oleh Champoux (2007, 12) yang menyatakan bahwa penggunaan media film dalam pembelajaran mampu mencapai ranah kognitif dan afektif siswa secara bersamaan, karena siswa dapat memperoleh pengalamanpengalaman belajar yang tidak diperolehnya pada pembelajaran tanpa menggunakan film.

Pada penelitian ini, peneliti sudah berusaha untuk melakukan penelitian semaksimal mungkin, namun pada praktiknya penelitian ini memiliki keterbatasan, yaitu: pertama, belum tersedianya buku penunjang pembelajaran yang mencukupi. Pengembalian sistem kurikulum dari kurikulum 2013 ke kurikulum 2006 menjadi salah satu alasan terbatasnya fasilitas buku Ekonomi berbasis kurikulum 2006 yang dimiliki siswa, sehingga peneliti harus lebih dulu mempersiapkan buku-buku tersebut dengan meminjamkannya pada perpustakaan sekolah. Keterbatasan kedua 
ialah bahwasanya penelitian ini belum mampu mengontrol seluruh variable yang mempengaruhi minat dan hasil belajar Ekonomi siswa, sehingga dapat dimungkinkan bahwa hasil penelitian ini bukanlah hasil yang mutlak karena peran film sebagai media pembelajaran Ekonomi.

\section{Simpulan dan Saran}

\section{Simpulan}

Berdasarkan pembahasan hasil penelitian yang telah dikemukakan di atas, diperoleh beberapa kesimpulan, yaitu: (1) Penggunaan film dalam pembelajaran terbukti efektif meningkatkan minat dan hasil belajar siswa. Hal ini ditunjukkan dari pengujian multivariat yang menghasilkan nilai Sig. $0,000<0,05$ yang berarti bahwa hipotesis pertama yang berbunyi "Film efektif meningkatkan minat dan hasil belajar Ekonomi siswa SMA" diterima, (2) Media film terbukti efektif dalam meningkatkan minat belajar ekonomi siswa. Hal ini terbukti dengan nilai rerata peningkatan skor minat belajar siswa kelas eksperimen yang lebih unggul 5,58 poin dari rerata peningkatan skor minat belajar siswa kelompok kontrol. Selain itu, pada pengujian hipotesis diperoleh nilai sig. $0,001<0,05$ yang berarti hipotesis kedua yang berbunyi "Terdapat perbedaan peningkatan minat belajar siswa yang menggunakan media film dengan siswa yang tidak menggunakan media film dalam pembelajaran Ekonomi" diterima, dan (3) Media film terbukti efektif dalam meningkatkan hasil belajar ekonomi siswa. Hal ini terbukti dengan perbandingan nilai rerata peningkatan kelompok eksperimen dan kelompok kontrol yang menunjukkan skor keduanya terpaut 9,35 dengan kelompok eksperimen yang lebih unggul (43.10 : 33.75). Selain itu, pada uji hipotesis diperoleh nilai sig. $0,014<0,05$ yang berarti hipotesis ketiga yang berbunyi "Terdapat perbedaan peningkatan hasil belajar siswa yang menggunakan media film dengan siswa yang tidak menggunakan media film dalam pembelajaran Ekonomi" diterima.

Implikasi

Sebagai implikasi dari temuan dalam penelitian ini ialah perlunya perhatian khusus terhadapa beberapa hal yang berkenaan dengan pelaksanaan pembelajaran dengan media film sebagai berikut:
Pertama, efektivitas film sebagai media pembelajaran untuk meningkatkan minat dan hasil belajar siswa dapat terwujud dengan adanya kesiapan guru dan fasilitas yang memadai. Kesiapan guru diantaranya meliputi kesiapan dalam penyusunan RPP (Rencana Pelaksanaan Pembelajaran), penguasaan materi pembelajaran, kesiapan metode dan media pembelajaran yang digunakan, dan kesiapan dalam manajemen waktu yang baik. Adapun kesiapan fasilitas diantaranya berupa LCD Projector, Mini Sound System, Laptop, dan kabel penyambung listrik.

Kedua, penggunaan film dalam pembelajaran harus dilakukan dengan langkah-langkah yang tepat. Hal ini untuk menjaga efektivitas penerapannya dalam pembelajaran sehingga dapat mewujudkan tujuan pembelajaran yang telah dirumuskan.

Ketiga, penggunaan film dalam pembelajaran harus disesuaikan dengan materi ajar dan tujuan pembalajaran yang telah dirumuskan. Relevansi antara film dan materi pembelajaran menjadi salah satu hal yang harus diperhatikan guru untuk mewujudkan efektivitas film untuk mencapai tujuan pembelajaran.

Saran

Beberapa saran yang diajukan peneliti untuk dijadikan pertimbangan dan pemikiran oleh kepala sekolah dan para guru ialah sebagai berikut:

Pertama, perlu adanya penggalakan pemanfaatan media pembelajaran di dalam kelas, terutama media audiovisual yang salah satunya berupa film. Hal ini untuk membantu pencapaian tujuan pembelajaran melalui peningkatan minat dan hasil belajar siswa yang mencakup pengetahuan dan pemahaman siswa pada materi yang disampaikan.

Kedua, perlunya peningkatan fasilitas pembelajaran pada masing-masing kelas, termasuk LCD projector, kabel penyalur listrik, mini sound system, dll. Hal ini untuk mendukung pelaksanaan pembelajaran dengan media audiovisual salah satunya berupa film.

Ketiga, pengoptimalan penggunaan media pembelajaran berupa audio-visual yang salah satunya adalah film dirasa sangat perlu dilakukan. Hal ini berkenaan dengan upaya membuat pembelajaran lebih menarik, menyenangkan, dan menghibur sehingga siswa memiliki minat yang 
tinggi untuk belajar. Selain itu, hal ini karena media audio visual, salah satunya media film telah terbukti mampu meningkatkan hasl belajar siswa.

Keempat, film yang digunakan dalam pembelajaran harus dipilih oleh guru berdasarkan kesesuaian film dengan tujuan dan materi pembelajaran. Selain itu guru juga harus mempersiapkan Rencana Pelaksanaan Pembelajaran (RPP), sistematika penugasan, sitematika penilaian, peralatan seperti LCD Projektor, sound system mini, dan kabel terminal atau penyambung listrik, laptop atau tablet (PC), dan lain sebagainya.

\section{Daftar Pustaka}

Champoux, J. E. (2007). Film as a Teaching Resouce. Journal of Management Inquiry 19998 (2): 240-251

Council Lottary Fundee, UK Film. (2010). Using Film in Schools: A Practical Guide, $21^{s t}$ Century Literacy. United Kingdom

Dale, Edgar. (1946). Audio-Visual Methods in Teaching. NY: Dryden Press

Hamalik, O. (2006). Proses Belajar Mengajar. Bandung: Bumi Aksara
Masterpiece. (2011). Film in the Classroom: A guide for Teacher (Rev. Ed). New York: WGBH Educational Foundation.

Morris, Wayne. (2006). Creativity: its Place in Education. New Zealand. Jpb. com.

Munadi, Yudhi. (2013). Media Pembelajaran; sebuah pendekatan baru. Jakarta. Referensi

Otte, R.W. (1966). Creativity in Teaching: Childhood Education Volume 43, Issue 1. Taylor fracis Online. Diunduh dari http:// www.tandfonline.com/doi/s/10.1080/00 094056.1966.10728017? journalCode $=u c$ ed20 pada16 Desember 2015

Wibowo, K., \& Marzuki, M. (2015). PENERAPAN MODEL MAKEA MATCH BERBANTUAN MEDIA UNTUK MENINGKATAN MOTIVASI DAN HASIL BELAJAR IPS. Harmoni Sosial: Jurnal Pendidikan IPS, 2(2), 158-169. Retrieved from http://journal.uny.ac.id/ index.php/hsjpi/article/view/7667/6608

Widoyoko, E.P. (2009). Evaluasi Program Pembelajaran, Panduan Praktis bagi Pendidik dan Calon Pendidik. Yogyakarta. Pustaka Pelajar 